\title{
Rancang Bangun Model Sistem Informasi Manajeman Aset Dengan Prototyping Model Pada Fakultas Teknik Universitas Lancang Kuning
}

\author{
Taslim $^{1}$, Dafwen Toresa ${ }^{2}$, Syahriatna ${ }^{3}$ \\ Teknik Informatika, Fakultas Ilmu Komputer Universitas Lancang Kuning \\ Jl. Yos sudarso km 8 Rumbai Pekanbaru Riau \\ Taslim@unilak.ac.id
}

Manajemen data aset adalah salah satu mekanisme untuk pengelolaan data aset yang terdapat pada sebuah perusahaan atau sebuah instansi. Pengelolaan data aset yang dibuat dengan aplikasi pengolah kata dan dikerjakan secara terpisah antar bagian tentu akan mengakibatkan lama serta lambatnya proses pengelolaan data aset yang ada. Sistem informasi manajemen aset dimaksudkan agar pengelolaan data aset yang ada dapat dikelola secara lebih cepat, efektif dan efisien dari segi waktu dan juga dapat dikelola dan diakses secara real time karena sistem ini dibangun agar dapat berjalan secara online dan berbasis multi user. Sistem manajemen aset ini membahas mulai dari pengadaan aset, penempatan aset sampai pemusnahan aset. Metoda penelitian dengan prototyping model yang digunakan pada penelitian ini bertujuan agar system yang dibangun dapat memenuhi semua keinginan dari si pengguna system. Perancangan system menggunakan alat bantu rancangan procedural yaitu context diagram, data flow diagram dan ER Diagram.

Keyword : Manajemen Data, asset, real time,multi user, online, prototyping model 